\title{
UANG PAKSA: TINJAUAN HUKUM KEUANGAN NEGARA
}

\author{
Yuli Indrawati ${ }^{1}$
}

\begin{abstract}
Abstrak
Forced money as a form of forced effort provided for in Law No. 9 Year 2004 concerning Amendment to Law No. 5 Year 1986 regarding State Administrative Court is not a punishment but plaintiff's efforts to protect the rights of compliance enforcement of the State Administrative Court (TUN) decision who already have permanent legal force and tool behavior modifiers TUN official or agency (including government) in implementing decision. Then the burden of forced payments must be in concurrent with the burden of these enforcement responsibilities, namely conveyed by the State or by officials (or body TUN). Thus the state will use the money effectively and in accordance with the purpose of conducting government in order to realize a just and prosperous society, physical and spiritual prosperity. Not for anything else.
\end{abstract}

Kata kunci: hukum administrasi negara, upaya paksa, uang paksa

\section{Pendahuluan}

Undang-undang No. 9 Tahun 2004 tentang Perubahan atas Undangundang No. 5 Tahun 1986 membawa perubahan antara lain dengan menerapkan upaya paksa bagi tidak terlaksananya putusan pengadilan TUN yang telah mempunyai kekuatan tetap dalam kurun waktu yang ditentukan (dalam UU) yaitu 3 bulan. Aturan tersebut tercantum dalam perubahan Pasal 116. Berikut rumusannya secara lengkap.

\begin{tabular}{|l|c|}
\hline Undang-undang 5 tahun 1986 & Undang-undang 9 tahun 2004 \\
\hline (1) Salinan putusan Pengadilan yang & \\
telah memperoleh kekuatan hukum & \\
tetap, dikirimkan kepada para pihak & \\
dengan surat tercatat oleh Panitera & \\
Pengadilan setempat atas perintah & idem \\
Ketua Pengadilan yang mengadilinya & \\
\hline
\end{tabular}

${ }^{1}$ Penulis adalah Staf Pengajar Fakultas Hukum Universitas Indonesia. Alamat korespondensi: yulifhui@yahoo.com. 


\begin{tabular}{|c|c|}
\hline $\begin{array}{l}\text { dalam tingkat pertama selambat- } \\
\text { lambatnya dalam waktu } 14 \text { (empat } \\
\text { belas) hari. }\end{array}$ & \\
\hline $\begin{array}{l}\text { (2) Dalam hal } 4 \text { (empat) bulan setelah } \\
\text { putusan Pengadilan yang telah } \\
\text { memperoleh kekuatan hukum tetap } \\
\text { sebagaimana dimaksud pada ayat (1) } \\
\text { dikirimkan, tergugat tidak } \\
\text { melaksanakan kewajibannya } \\
\text { sebagaimana dimaksud dalam Pasal } \\
97 \text { ayat (9) huruf a, Keputusan TUN } \\
\text { yang disengketakan itu tidak } \\
\text { mempunyai kekuatan hukum lagi. }\end{array}$ & idem \\
\hline $\begin{array}{l}\text { (3) Dalam hal tergugat ditetapkan harus } \\
\text { melaksanakan kewajibannya } \\
\text { sebagaimana dimaksud dalam Pasal } \\
97 \text { ayat (9) huruf b dan c, dan } \\
\text { kemudian setelah } 3 \text { (tiga) bulan } \\
\text { ternyata kewajiban tersebut tidak } \\
\text { dilaksanakannya, penggugat } \\
\text { mengajukan permohonan kepada } \\
\text { Ketua Pengadilan sebagaimana } \\
\text { dimaksud pada ayat (1) agar } \\
\text { Pengadilan memerintahkan tergugat } \\
\text { melaksanakan putusan Pengadilan } \\
\text { tersebut. }\end{array}$ & idem \\
\hline $\begin{array}{l}\text { (4) Jika tergugat masih tetap tidak mau } \\
\text { melaksanakannya, Ketua Pengadilan } \\
\text { mengajukan hal itu kepada instansi } \\
\text { atasannya menurut jenjang } \\
\text { jabatannya; }\end{array}$ & $\begin{array}{l}\text { (4) Dalam hal tergugat tidak bersedia } \\
\text { melaksanakan putusan Pengadilan } \\
\text { yang telah memperoleh kekuatan } \\
\text { hukum tetap, terhadap pejabat yang } \\
\text { bersangkutan dikenakan upaya paksa } \\
\text { berupa pembayaran sejumlah uang } \\
\text { paksa dan/atau sanksi administratif. }\end{array}$ \\
\hline $\begin{array}{l}\text { (5) Instansi atasan sebagaimana dimaksud } \\
\text { dalam ayat (4) dalam waktu dua } \\
\text { bulan setelah menerima } \\
\text { pemberitahuan dari Ketua Pengadilan } \\
\text { harus sudah memerintahkan Pejabat } \\
\text { sebagaimana dimaksud dalam ayat } \\
\text { (3) melaksanakan putusan } \\
\text { Pengadilan tersebut; }\end{array}$ & $\begin{array}{l}\text { (5) Pejabat yang tidak melaksanakan } \\
\text { putusan pengadilan sebagaimana } \\
\text { dimaksud pada ayat (4) diumumkan } \\
\text { pada media massa cetak setempat } \\
\text { oleh Panitera sejak tidak } \\
\text { terpenuhinya ketentuan sebagaimana } \\
\text { dimaksud pada ayat (3). }\end{array}$ \\
\hline $\begin{array}{l}\text { (6) Dalam hal instansi atasan } \\
\text { sebagaimana dimaksud dalam ayat } \\
\text { (4) tidak mengindahkan ketentuan } \\
\text { sebagaimana dimaksud dalam ayat }\end{array}$ & dihapus \\
\hline
\end{tabular}


(5), maka Ketua Pengadilan mengajukan hal itu kepada Presiden sebagai pemegang kekuasaan pemerintahan tertinggi untuk memerintahkan pejabat tersebut melaksanakan putusan Pengadilan tersebut.

Berbeda dengan pelaksanaan putusan perkara perdata di pengadilan umum, pelaksanaan putusan pada pengadilan TUN tidak dikenal pelaksanaan putusan secara riil, ${ }^{2}$ akan tetapi pelaksanaan putusan dilaksanakan secara administratif. Pengawasan terhadap pelaksanaan putusan pengadilan TUN berdasarkan UU No. 5 Tahun 1986 menitikberatkan pada institusi organisasi administrasi negara dimana pejabat atau badan TUN berada dari atasan langsungnya sampai ke jenjang tertinggi (Presiden), Berarti pelaksanaan putusan sangat bergantung pada itikad organisasi administrasi negara tersebut. Hal ini berdampak kurang baik bagi penggugat karena meski ada putusan hakim yang berkekuatan hukum tetap tetapi pelaksanaannya masih harus bergantung pada institusi tergugat dimana terbuka peluang untuk tidak dilaksanakan. Dan tidak ada upaya lanjutan terhadap tidak terlaksananya putusan tersebut yang bersifat memaksa dari luar institusi pihak tergugat.

Sedangkan UU No. 9 Tahun 2004 menekankan pengawasan pelaksanaan putusan pada institusi hukum dan institusi sosial masyarakat. Pengawasan pelaksanaan putusan melalui institusi hukum dilakukan berupa upaya pemaksa dalam bentuk uang paksa dan sanksi administratif. Kontrol hukum lebih mempunyai kekuatan dibandingkan dengan kontrol internal organisasi. Karena kontrol hukum mengandung daya paksa tuntutan untuk dilaksanakan.

Pengawasan melalui institusi sosial masyarakat dilakukan melalui diumumkannya pejabat yang tidak melaksanakan putusan pengadilan tersebut pada media cetak setempat. Meski daya paksa kontrol sosial tidaklah sekuat daya paksa kontrol hukum, akan tetapi justru dapat berdampak pada menurunnya tingkat kepercayaan masyarakat atas institusi organisasi administrasi negara. Padahal kepercayaan masyarakat sangat penting bagi keberlangsungan pelaksanaan pemerintahan.

Terkait dengan perubahan tersebut ada beberapa hal yang menarik untuk dikaji lebih lanjut dari segi hukum administrasi Negara, antara lain dari segi organisasi pemerintahan, kepegawaian, dan keuangan. Akan tetapi pembahasan akan difokuskan pada beban pembayaran uang paksa atau

${ }^{2}$ Indonesia, Undang-Undang Nomor. 5 Tahun 1986 Tentang Peradilan Tata Usaha Negara, Pasal 97 ayat (9). 
tanggung jawab pembayaran uang paksa (dari segi hukum keuangan negara sesuai dengan judul artikel ini).

\section{Pembahasan}

\section{A. Upaya Paksa}

Setiap putusan pengadilan yang telah mempunyai kekuatan hukum tetap harus dilaksanakan sesegera mungkin - tidak boleh ditunda oleh pihak yang diberi kewajiban untuk melaksanakan sesuatu. Hal ini dimaksudkan agar ada kepastian hukum dan perlindungan hukum bagi pihak lain. Itulah sebabnya pelaksanaan putusan pada pengadilan TUN diberikan jangka waktu maksimal yaitu 3 bulan. Apabila batas waktu pelaksanaan putusan terlampaui, pihak yang dibebani kewajiban untuk melaksanakan sesuatu (dalam hal ini tergugat) akan dikenakan upaya paksa (Pasal 116 ayat 4 UU No. 9 Tahun 2004)

Upaya paksa adalah suatu bentuk paksaan untuk melaksanakan putusan pengadilan yang telah mempunyai kekuatan hukum tetap. Upaya ini diberlakukan bagi tergugat yang tidak melaksanakan putusan tersebut dalam waktu yang telah ditetapkan dalam peraturan perundang-undangan. Adapun upaya paksa dapat berupa:

a. Pembayaran sejumlah uang paksa; dan/atau

b. Sanksi administratif.

Diluar upaya paksa tersebut juga diterapkan upaya lain (dapat pula disebut sebagai daya paksa secara sosial/moral), yaitu berupa pengumuman pada media massa cetak setempat oleh Panitera.

Ada beberapa pemikiran yang kiranya menjadi latar belakang penerapan uang paksa dalam peradilan TUN. Pertama, pelaksanaan putusan pada hukum acara peradilan TUN dilakukan secara administratif oleh pejabat atau badan TUN yang bersangkutan (pihak tergugat). Seperti telah dikemukakan sebelumnya, hal ini menyebabkan pemenuhannya sangat bergantung pada kehendak dan kemauan (itikad baik) dari tergugat untuk melaksanakannya. Keadaan ini kurang menguntungkan bagi penggugat karena ada peluang kemungkinan tidak dipenuhinya putusan. Memang dalam pasal 116 ayat 3-6 UU No. 5 Tahun 1986 mengatur upaya yang dapat dilakukan penggugat dalam hal putusan tidak dilaksanakan, yaitu dengan mengajukan permohonan kepada Ketua Pengadilan untuk memerintahkan pelaksanaan putusan dan apabila masih membangkang 
maka Ketua Pengadilan mengajukan hal itu kepada instansi atasan (sampai kepada Presiden sebagai pucuk pimpinan organisasi pemerintahan) agar memerintahkan tergugat melaksanakan putusan. Pengaturan tersebut tetap menimbulkan kekhawatiran dan kurang menjamin adanya pemenuhan pelaksanaan putusan karena pihak yang melakukan pengawasan (atau memberikan perintah) berada dalam satu organisasi yaitu organisasi pemerintah (yang dalam hal ini adalah pihak tergugat pula) dimana tidak terdapat daya paksa sehingga dirasa kurang efektif. Dengan demikian, pengaturan tersebut tidak berarti banyak dalam memberikan perlindungan dan kepastian hukum bagi penggugat untuk mendapatkan haknya sesuai dengan putusan pengadilan yang telah mempunyai kekuatan hukum tetap. Dengan demikian hak penggugat akan terlaksananya putusan tidak terjamin karena tidak ada paksaan pelaksanaan putusan (execution force).

$K e d u a$, terdapat perbedaan status dan kedudukan antara penggugat dan tergugat dalam kehidupan bernegara. Penggugat adalah seseorang atau badan hukum perdata ${ }^{3}$ selaku warga masyarakat. Sedangkan tergugat adalah Badan atau Pejabat $\mathrm{TUN}^{4}$ selaku aparat yang menyelenggarakan tugas pemerintahan. Dalam teori ketatanegaraan rakyat merupakan pihak yang dikuasai dan pemerintah selaku penguasa dengan berbagai perangkat kekuasaannya. Kedudukan badan atau pejabat TUN ini jelas lebih tinggi dan lebih kuat ${ }^{5}$ dibanding dengan warga masyarakat biasa. Perbedaan kedudukan inilah yang mendasari dibentuknya Peradilan TUN yang akan memberikan perlindungan hukum bagi pihak yang lebih lemah (rakyat) yang merasa dirugikan atas tindakan pihak yang lebih kuat (pemerintah). Seiring dengan jalannya waktu, ternyata keberadaan Peradilan TUN tidak cukup untuk memberikan perlindungan pada rakyat pencari keadilan karena terdapat peluang kemungkinan putusan pengadilan yang mempunyai kekuatan hukum tetap tidak dilaksanakan. Untuk lebih memberikan perlindungan kepada rakyat diberikan jaminan atas pelaksanaan putusan pengadian yang telah mempunyai kekuatan hukum tetap melalui upaya paksa. Dengan kata lain, upaya paksa ini merupakan upaya terbaik sebagai wujud perlindungan hak tergugat

${ }^{3}$ Pasal 1 angka 6 jo Pasal 53 UU No. 5 Tahun 1986.

${ }^{4}$ Pasal 1 angka 6 UU No. 5 Tahun 1986.

${ }^{5}$ Indroharto menggunakan istilah pemerintah menduduki posisi khusus dan unik, kalau tidak dikatakan sangat istimewa. Lihat Indroharto, "Usaha Memahami Undang-undang Tentang Peradilan Tata Usaha Negara", hal. 71. 
untuk mendapatkan pemenuhan haknya atas pelaksanaan putusan (secara paksa).

\section{B. Uang Paksa}

Uang paksa merupakan sejumlah uang yang harus dibayarkan pejabat yang bersangkutan atas tidak terlaksananya putusan pengadilan dalam kurun waktu yang telah ditentukan.

Uang paksa telah dikenal dalam hukum acara peradilan perdata (istilah yang digunakan adalah $d$ wangsom). Meski pengaturannya tidak terdapat dalam HIR (Herzien Indonesis Reglement) sebagai peraturan yang mengatur tentang hukum acara peradilan perdata, tetapi uang paksa diatur dalam pasal 606a dan b Rv (Reglement op de Burgerlijke Rechtsverordering). ${ }^{6}$ Uang paksa harus dibayar oleh tergugat selama ia tidak memenuhi/melaksanakan putusan. Penerapan uang paksa tidaklah berlaku bagi semua jenis putusan, ${ }^{7}$ akan tetapi hanya berlaku bagi putusan yang bersifat condemnatoir. Hal ini dikarenakan putusan tersebut mewajibkan pihak tergugat untuk melakukan sesuatu berupa pemenuhan akan suatu prestasi dan mengakui hak dari penggugat. Untuk itu perlu perlindungan bagi penggugat akan pelaksanaan putusan tersebut melalui uang paksa. Dengan kata lain, uang paksa akan memaksa tergugat untuk melaksanakan putusan pengadilan secara paksa (execution force).

Dalam hukum acara peradilan tata usaha Negara, uang paksa juga hanya diterapkan secara limitatif yaitu bagi putusan yang di dalam diktumnya memuat kewajiban:

a. pencabutan keputusan TUN (yang disengketakan) dan menerbitkan keputusan TUN yang baru; dan

b. penerbitan keputusan TUN dalam hal gugatan didasarkan pada Pasal 3. ${ }^{8}$

6 Sudikno Mertokusumo, "Hukum Acara Perdata Indonesia", Cetakan Pertama, (Yogyakarta: Liberty, 1988), hal. 45.

${ }^{7}$ Dalam hukum acara perdata dikenal 3 macam putusan yaitu putusan yang bersifat constitutive (menciptakan), putusan yang bersifat declaratoir (menerangkan atau menyatakan), dan putusan yang bersifat condemnatoir (mewajibkan).

${ }^{8}$ Pada Peradilan Tata Usaha Negara dikenal 3 macam kewajiban, yang harus dilakukan oleh badan atau pejabat TUN yang mengeluarkan keputusan TUN, yang dapat dicantumkan dalam putusannya, yaitu berupa:

a. pencabutan keputusan TUN yang bersangkutan; atau 
Uang paksa ini, seperti halnya dalam hukum acara peradilan perdata, dimaksudkan (sebagai salah satu upaya) untuk memberikan perlindungan akan pemenuhan hak penggugat sebagaimana diputuskan oleh pengadilan.

Sebagai perbandingan, dalam hukum administrasi Negara Jerman, ${ }^{9}$ uang paksa (Zwangsgeld) dimaksudkan untuk mengubah perilaku pejabat atau badan TUN atas putusan pengadilan TUN. ${ }^{10}$ Uang paksa bukan merupakan hukuman ataupun akibat dari perbuatan melawan hukum. Oleh karena itu uang paksa dapat dikenakan ulang dan ditingkatkan apabila tergugat tetap membangkang. Sebaliknya apabila tergugat untuk sementara itu (pada saat masih dalam proses pengajuan permohonan zwangsgeld) telah melaksanakan kewajibannya maka uang paksa dapat ditiadakan (tidak diterapkan). Pembayaran uang paksa tidak menghilangkan kewajiban tergugat untuk melaksanakan putusan pengadilan. Dalam UU (Verwaltungsvollstrekungsgezet) dikatakan bahwa uang paksa diterapkan dengan sangat cermat - harus mencapai tujuannya. Oleh karena itu pembebanan uang paksa dibatasi jumlahnya 3 sampai 2.000 DM.

b. pencabutan keputusan TUN yang bersangkutan dan menerbitkan keputusan TUN yang baru;

c. penerbitan keputusan TUN dalam hal gugatan didasarkan pada Pasal 3.

Lihat Pasal 97 ayat (9) UU No. 5 Tahun 1986 tentang Peradilan Tata Usaha Negara.

${ }^{9}$ Artikel 11Verwaltungsvollstrekungsgezet (VwVG):

(1) Kann eine Handlung durch einen anderen nicht vorgenommen werden und haengt sie nur vom Willen des Pflichtigen ab, so kann der Pflichtige zur Vornahme der Handlung durch ein Zwangsgeld angehalten warden. Bei vertretbaren Handlungen kann es verhaengt warden, wenn die Ersatzvornahme untunlich ist, besonders, wenn der Pflichtige ausserstande ist, die Kosten zu tragen, die aus der Ausfuehrung durch einen anderen entstehen.

(2) Das Zwangsgeld ist auch zulaessig, wenn der Pflichtige der Verpflichtung zuwiderhandelt, eine Handlung zu dulden oder zu unterlassen.

(3) Die Hoehe des Zwangsgeld betraegt mindestens drei Deutsche Mark und hoechstens zweitausend Deutsche Mark.

10 Lihat Hartmut Maurer, "Allgemeines Verwaltungsrecht", cetakan ke-11, (Muenchen: C.H. Beck, 1997), hal. 482.

Das Zwangsgeld ist keine Strafe, sondern ein Beugemittel, also keine Reaktion auf begangenes Unrecht, sondern Mittel zur Erzwingung kuenftigen Verhaltens. Daraus folgt:

Das Zwangsgeld kann wiederholt und gesteigert werden, wenn der Pflichtige renitent bleibt;

- das Zwangsgeld darf nicht vollstreckt werden, wenn der Pflichtige inzwischen seiner Verpflichtung nachgekommen ist;

- $\quad$ das Zwangsgeld ist neben einer etwaigen Kriminalstrafe oder Geldbusse zulaessig. 
Meski pada UU No. 9 Tahun 2004 tidak dirumuskan secara jelas tujuan dari pengenaan uang paksa akan tetapi terdapat beberapa hal yang dapat dijadikan dasar untuk melakukan analisa, yaitu:

- uang paksa ditetapkan setelah masa waktu pelaksanaan putusan terlewati ( 3 bulan),

- uang paksa merupakan suatu upaya paksa,

- uang paksa hanya merupakan salah satu bentuk upaya paksa,

Dengan demikian uang yang dibayarkan merupakan suatu paksaan untuk melaksanakan sesuatu (melaksanakan putusan) yang telah melewati batas waktu yang ditentukan. Apabila tergugat tidak mau dikenakan uang paksa maka ia harus melaksanakan putusan dalam waktu yang ditentukan. Oleh karena itu dapat diasumsikan bahwa uang paksa dimaksudkan sebagai kompensasi yang harus dibayarkan tergugat atas keterlambatan pemenuhan pelaksanaan putusan yang menjadi kewajibannya dan memberikan efek jera bagi tergugat (khususnya) dan pejabat atau badan TUN lainnya untuk menghormati putusan pengadilan dan tidak mengabaikannya begitu saja. Jadi UU No. 9 Tahun 2004 mengandung arti dan maksud (sama halnya dengan yang dianut dalam hukum administrasi Negara Jerman) bahwa uang paksa bukan merupakan hukuman atas tidak dilaksanakannya putusan pengadilan tetapi merupakan suatu upaya untuk mengubah perilaku pejabat atau badan TUN di masa mendatang.

Maka, uang paksa mempunyai efek ganda yaitu bagi penggugat sebagai jaminan perlindungan pemenuhan haknya (sebagaimana yang ditetapkan dalam putusan pengadilan) dan bagi tergugat adalah sebagai upaya untuk mengubah perilakunya untuk melaksanakan putusan pengadilan dalam waktu yang ditentukan.

\section{Beban Pembayaran Uang Paksa}

Sebagaimana diatur dalam UU No. 5 Tahun 1986, tergugat adalah pejabat atau badan TUN, yang merupakan aparat pelaksana urusan pemerintahan. Mengingat status dan kedudukan tergugat sebagai aparat pemerintahan yang notabene adalah pejabat administrasi Negara, maka pelaksanaan putusan terkait pula dengan pertanggungjawaban administrasi Negara.

Pertanggungjawaban administrasi Negara seringkali dikaitkan dengan dapat-tidaknya administrator Negara (pejabat atau badan TUN) digugat di pengadilan untuk bertanggung jawab atas kerugian yang diderita oleh masyarakat atas perbuatan atau tindak administrasi 
Negara yang dilakukannya. Berikut akan dikemukakan paham yang dianut oleh beberapa Negara.

Dalam hukum administrasi Negara Inggris, setiap warga Negara dapat menggugat tanggung jawab dari pejabat atau badan TUN yang telah melakukan tindakan yang menimbulkan kerugian baginya. Tanggung jawab ditentukan oleh penyebab kerugian tersebut. ${ }^{11}$

Hukum administrasi Negara Perancis menganut paham bahwa tanggung jawab dari pejabat atau badan TUN bergantung pada resiko atau kesalahan yang ditimbulkan akibat perbuatan atau tindakan administrasi Negara yang dilakukannya. Pejabat atau badan TUN dapat dimintai pertanggungjawaban walaupun tidak melakukan kesalahan secara langsung (sanc faute). Hal ini didasarkan pada kesetaraan beban publik. Perbedaan jenis kesalahan akan membedakan pengadilan yang berwenang untuk mengadilinya. Kesalahan pejabat atau badan TUN yang dilakukan bukan dalam rangka pelayanan publik (faute personelle) yang disebabkan oleh ketidakhati-hatian dapat diajukan gugatannya ke pengadilan negeri. Sedangkan apabila kesalahan terjadi dalam rangka pelayanan publik (faute de service) dapat digugat ke pengadilan administrasi. ${ }^{12}$

Dalam sistem hukum Indonesia juga diatur mengenai pertanggungjawaban administrasi negara atas perbuatan atau tindakan administrasi negara yang menimbulkan kerugian pada masyarakat. Dalam hal ini masyarakat dapat mengajukan tuntutan ke pengadilan TUN (obyek gugatan adalah keputusan TUN) dan pengadilan negeri (untuk perbuatan lainnya).

Pertanggungjawaban administrasi Negara selain dapat dilihat dari dapat tidaknya perbuatan pejabat atau badan TUN yang merugikan masyarakat digugat di pengadilan, dapat pula ditinjau dari pihak yang harus mempertanggungjawabkan perbuatan tersebut. Berikut akan diuraikan beberapa paham yang dianut oleh hukum administrasi Negara di negara lain dan juga pendapat para ilmuwan.

Dalam hukum administrasi Negara Jerman, tanggung jawab dibedakan dalam 4 kategori yaitu tanggung jawab individu pejabat, tanggung jawab Negara, tanggung jawab (organisasi) administrasi

11 J. Bell and A.W. Bradley, "Government Liability: A Comparative Study", (London: United Kingdom National Committee of Comparative Law, 1991), Ch. 2.

12 R. Errera, "The Scope and Meaning of No-Fault Liability in French Administrative Law", (1986), "Current Legal Problem", hal. 171 - 172: C. Harlow, "Compensation and Government Torts", (London, 1982), hal. 102. 
Negara, dan tanggung jawab kumulatif. ${ }^{13}$ Pejabat bertanggung jawab secara individu karena kesalahan pribadi. Apabila kesalahan secara tidak langsung disebabkan oleh Negara maka Negara yang menanggungnya. Tanggung jawab (organisasi) administrasi Negara diterapkan apabila kesalahan dilakukan oleh pejabat administrasi Negara dalam rangka pelaksanaan tugas Negara. Dalam hal ini Negara harus memikul tangung jawab tersebut karena secara langsung pejabat administrasi Negara adalah wakil Negara dalam pelaksanaan tugasnya. Tanggung jawab kumulatif dimaksudkan bahwa tanggung jawab tersebut dipikul bersama oleh pejabat dan Negara.

Hukum administrasi Negara Perancis (dalam Yurisprudensi Counsil d'Etat) membagi tanggung jawab administrasi Negara dalam tanggung jawab yang dipikul oleh pejabat (faute de personelle) dan yang dipikul oleh Negara (faute de serve). Pejabat wajib memikul tanggung jawab secara pribadi apabila kesalahan disebabkan olehnya. Kesalahan tersebut diakibatkan adanya kekeliruan melakukan tindakan berdasarkan kehendaknya dalam rangka pelaksanaan fungsi tugas pemerintahan ataupun tindakan tersebut murni dilakukan di luar pelaksanaan fungsi tugas pemerintahan. Sedangkan Negara memikul tanggung jawab sepanjang pejabat melakukan tindakan yang keliru diluar kehendaknya dalam rangka pelaksanaan fungsi tugas pemerintahan.

Dalam hukum administrasi Negara Indonesia, pembebanan tanggung jawab oleh pejabat administrasi Negara diatur dalam UU No. 9 Tahun 2004 (Pasal 116). Pembebanan pembayaran uang paksa tidak dapat begitu saja dinyatakan dibebankan kepada Negara atau pejabat adminsitrasi. Apalagi jika terkait dengan pembebanan oleh Negara yang harus dilakukan secara cermat dengan memperhatikan adanya pembatasan penggunaan uang negara yaitu hanya digunakan dalam rangka pencapaian tujuan negara. Untuk itu terdapat beberapa hal yang

${ }^{13}$ Harmut Maurer, Op. Cit., hal. 616.

Die verschiedenen Haftungsmodelle:

a) Beamtenhaftung (persoenliche Haftung, Eigenhaftung): Der Beamte hat selbst und ausschliesslich den von ihm verursachten Schaden zu ersetzen.

b) Staatshaftung: Der Staat muss sich das Fehlverhalten seines Beamten unmittelbar zerechnen lassen und ausschliesslich fuer den Schaden einstehen.

c) Amtshaftung: Die Haftung trifft zunaechst den Beamten selbst, wird aber vom Staat uebernommen. Es liegt also eine Haftungsuebernahme vor mit der Folge, dass anstelle des Beamten der Staat den Schaden zu ersetzen hat. Im Gegensatz zu b) besteht keine unmittelbareoder originaere, sondern eine mittelbare oder derivative Staatshaftung.

d) Kumulative Haftung: Der Beamte und der Staat haften nebeneinander. 
dapat dijadikan bahan pertimbangan untuk menentukan pembebanan tanggung jawab pembayaran uang paksa, yaitu:

1. Mengacu pada bentuk kedua dari upaya paksa yaitu sanksi administratif.

Sanksi administratif hanya dapat dibebankan pada pejabat administrasi Negara bukan pada Negara.

2. Sebagai bahan pertimbangan, dalam Rancangan Peraturan Pemerintah (RPP) tentang Upaya Administratif yang merupakan peraturan pelaksanaan dari RUU tentang Administrasi Pemerintahan. Pasal 20 menyebutkan sebagai berikut.

(1) Ganti kerugian kepada pemohon yang dibebankan oleh perubahan kebijakan pemerintah, pelaksanaannya dibebankan kepada APBN atau APBD dari instansi pemerintah yang bersangkutan.

(2) Ganti kerugian kepada pemohon yang disebabkan oleh kelalaian, ketidakhati-hatian, atau terjadinya KKN pelaksanaan ganti rugi menjadi beban tanggung jawab dari pejabat yang mengeluarkan keputusan administrasi pemerintahan.

(3) Pelaksanaan ketentuan sebagaimana dimaksud pada ayat (2) dapat dibayar dulu dari sumber APBN/APBD.

(4) Pembebanan ganti kerugian sebagaimana dimaksud pada ayat (3) kepada pejabat administrasi pemerintahan dilaksanakan melalui proses tuntutan ganti kerugian berdasarkan ketentuan Undang-undang No. 17 Tahun 2003.

Dengan demikian tanggung jawab Negara hanya dapat diterapkan secara limitatif yaitu sepanjang adanya perubahan kebijakan saja. Penyebab lainnya akan menjadi beban tanggung jawab pribadi.

3. ditinjau dari aspek status dan kedudukan pejabat atau badan TUN pada proses keterlambatan pelaksanaan putusan.

Pejabat atau badan TUN merupakan organ negara yang menjalankan fungsi tertentu dari negara sebagaimana ditetapkan oleh peraturan perundang-undangan yang berlaku. Menurut Bothlingk, pejabat mewakili pemerintah/Negara. Walaupun mereka berganti-ganti tetapi selalu mewakili pemerintah dalam lingkungan kerja yang sama. Oleh karena itu perlu dimasukkan suatu pengertian yaitu "badan". Badan inilah yang kelak bertindak mewakili pemerintah. Untuk dapat disebut pejabat, maka seseorang harus bertindak sebagai badan (yaitu melakukan tindakan yang mewakili pemerintah atau sesuai dengan fungsi 
tertentu yang ditetapkan Negara untuknya melalui peraturan perundang-undangan). Dengan demikian seorang pejabat memiliki dua personifikasi yaitu sebagai individu dan sebagai badan atau pejabat. ${ }^{14}$

Logemann juga sependapat dengan Bothlingk yang menyatakan bahwa apabila pejabat bertindak atas nama jabatannya, maka jabatan itu menjadi pribadi. Artinya meskipun jabatan itu diwakili oleh pejabat, akan tetapi jabatannya yang dibebani kewajiban dan yang berwenang melakukan tindakan hukum termasuk bertindak sebagai pihak dalam hukum acara di peradilan administrasi. ${ }^{15}$

Menurut Stroink, pendapat Logemann tersebut hanya meninjau dari segi sosiologis. Padahal untuk memahami pengertian jabatan dan fungsi tidak hanya tinjauan sosiologis saja yang harus dilakukan tapi juga dibutuhkan tinjauan juridis. Ditinjau dari aspek hukum tata Negara, tidak setiap lingkungan pekerjaan sama keterkaitannya, walaupun penting adanya wewenang untuk melakukan tindakan hukum publik. Kedua, yang dipersonifikasi bukanlah fungsi, melainkan personifikasi kualitas. Kualitas diartikan sebagai kedudukan (sifat dan komposisi) dari orang yang berwenang melakukan tindakan hukum publik. Sedangkan apabila fungsi atau lingkungan kerja dipersonifikasikan, maka hal tersebut tidak berhubungan dengan sifat dari orangnya. ${ }^{16}$

Pengertian fungsi dalam arti juridis, menurut Stroink, adalah wewenang yang merupakan kekuasaan juridis seseorang. Dalam ranah hukum publik, pengertian wewenang dirumuskan sebagai kekuasaan juridis dari suatu jabatan. Oleh karena itu sifat jabatan yang terletak dalam hukum publik, melahirkan kewenangan publik. Kewenangan tersebut berupa kewenangan untuk melakukan tindakan hukum publik. Dengan demikian tergambarkan adanya keterkaitan antara kewenangan (fungsi) dan jabatan. ${ }^{17}$

Sejalan dengan pemikiran diatas, Kelsen berpendapat bahwa secara formal organ (Bothlingk menggunakan istilah pejabat atau

14 AnnaErliyana, "Keputusan Presiden Analisis Keppres R.I. 1987 - 1998", (Jakarta: Pasca Sarjana FHUI, 2005), hal. 182.

${ }^{15}$ Ibid., hal $182-183$.

${ }^{16}$ Ibid.

${ }^{17}$ Ibid. 
badan) adalah individu yang menjalankan suatu fungsi tertentu. Kualitas seseorang sebagai organ dibentuk oleh fungsinya. Dia adalah seorang organ karena dan sepanjang dia melakukan fungsi membuat dan menerapkan hukum (sesuai dengan fungsi administrasi Negara). Secara material, seseorang adalah organ Negara hanya jika dia secara pribadi menempati suatu kedudukan hukum tertentu, yaitu karena dipilih atau diangkat untuk menduduki fungsinya. Kualitas fungsi sebagai tindakan Negara dibentuk oleh kualitas individu yang menjalankan tindakan tersebut dalam kapasitasnya sebagai organ. ${ }^{18}$

Peraturan perundang-undangan memberikan kewenangan bagi pejabat atau badan TUN untuk menjalankan fungsi tertentu dari Negara berupa hak dan kewajiban negara. Berdasarkan penetapan tersebut pejabat atau badan TUN merupakan organ Negara. Hak dan kewajiban Negara adalah merupakan hak dan kewajiban para individu yang dalam memenuhi kewajiban dan menjalan hak ini memiliki kapasitas sebagai organ Negara. Hak dan kewajiban Negara tersebut adalah hak dan kewajiban dari para individu yang, menurut kriteria kita, harus dianggap sebagai organ Negara, yakni, yang menjalankan fungsi tertentu yang ditetapkan oleh tata hukum. Fungsi ini bisa berisi kewajiban ataupun hak. Fungsi merupakan isi suatu kewajiban jika seseorang individu bertangung jawab atas suatu sanksi seandainya fungsi tersebut tidak dijalankan. Sanksi ini tidak ditujukan kepada individu dalam kapasitasnya sebagai organ Negara. Pelanggaran kewajiban oleh organ Negara, yakni delik yang ditimbulkan oleh fakta bahwa suatu organ Negara tidak menjalankan fungsinya menurut cara yang ditetapkan oleh tata hukum, tidak dapat dituduhkan kepada Negara, karena seseorang individu adalah organ Negara (khususnya, pejabat Negara atau pegawai negeri) hanya sepanjang perbuatannya sesuai dengan norma hukum yang menentukan fungsinya. Sepanjang dia melanggar norma hukum, dia bukan organ Negara. ${ }^{19}$ Perbuatan yang dilakukan pejabat atau badan TUN diluar fungsi Negara yang ditetapkan tersebut tidaklah termasuk dalam kategori perbuatan organ Negara. Atau dapat

${ }^{18}$ Hans Kelsen, "General Theory of Law and State", (Terjemahan: Teori Umum Hukum dan Negara), alih bahasa oleh Somardi, (Jakarta: Bee Media Indonesia, 2007), hal. 239.

${ }^{19}$ Ibid., hal. $245-247$. 
dikatakan bahwa tidaklah mutlak perbuatan atau tindakan dari pejabat atau badan TUN merupakan perbuatan Negara. Karena kualitas seseorang sebagai organ dibentuk oleh fungsinya.

Dengan kata lain, Negara dapat dimintai pertanggungjawaban hanya terbatas pada perbuatannya saja. Perbuatan pejabat atau badan TUN yang melaksanakan fungsi Negara yang ditetapkan sajalah yang menjadi tanggung jawab Negara. Perbuatan pejabat atau badan TUN diluar fungsi Negara yang ditetapkan untuknya menjadi tanggung jawab pribadi pejabat atau badan TUN tersebut.

4. Sebagai perbandingan dapat pula ditinjau dari ketentuan ganti rugi yang berlaku bagi pejabat Negara, pegawai negeri dan bendahara sebagaimana diatur dalam UU No. 17 Tahun 2003 Tentang Keuangan Negara dan UU No. 1 Tahun 2004 Tentang Perbendaharaan Negara. Setiap pejabat Negara, pegawai negeri dan bendahara yang melanggar hukum atau melalaikan kewajiban yang dibebankan kepadanya baik secara langsung maupun tidak langsung yang mengakibatkan terjadinya kerugian keuangan Negara diwajibkan untuk bertanggung jawab secara pribadi atas kerugian tersebut. ${ }^{20}$ Kerugian keuangan Negara dapat terjadi karena pelanggaran hukum atau kelalaian pejabat Negara atau pegawai negeri bukan bendahara dalam rangka pelaksanaan kewenangan administratif. Sedangkan kerugian keuangan Negara yang dilakukan bendahara dalam rangka pelaksanaan kewenangan kebendaharaan. Ketentuan untuk menanggung beban pertanggungjawaban secara pribadi juga berlaku bagi pejabat lain yang berstatus bukan pejabat Negara, pegawai negeri, ataupun bendahara yang menyelenggarakan tugas pemerintahan dan kenegaraan sepanjang ia melakukan perbuatan yang secara langsung menyebabkan kerugian pada keuangan Negara.

Penyelesaian kerugian keuangan Negara perlu segera dilakukan untuk mengembalikan kekayaan Negara yang hilang atau berkurang serta untuk meningkatkan disiplin dan tanggung jawab para pegawai negeri/pejabat Negara pada umumnya dan para pengelola keuangan pada khususnya. Dengan penyelesaian kerugian tersebut Negara dapat dipulihkan dari kerugian yang telah terjadi. Kewajiban untuk

${ }^{20}$ Pasal 35 UU No. 17 Tahun 2003 jo Pasal 59-67 UU No. 1 Tahun 2004. Khusus untuk bendahara jo Pasal 22 - 23 UU No. 15 Tahun 2004 Tentang Pemeriksaan Pengelolaan dan Tanggungjawab Keuangan Negara. 
mengganti kerugian keuangan Negara merupakan salah satu bentuk pengendalian intern yang andal.

Dari ketentuan ini tergambarkan bahwa perbuatan yang merugikan keuangan Negara ditanggung secara pribadi oleh pejabat yang bersangkutan. Negara sama sekali tidak dibebani kewajiban untuk bertanggung jawab. Kerugian harus diganti oleh pihak yang melakukan kesalahan. Akan tetapi, harus dibuktikan terlebih dahulu adanya kerugian pada keuangan Negara.

Pertanggungjawaban yang harus dilakukan dapat berupa mengganti sejumlah uang atas kerugian keuangan Negara yang telah terjadi, sanksi adminsitratif, dan/atau pidana (jika ditemukan unsur pidana pada penyebab terjadi kerugian keuangan Negara tersebut).

Dengan demikian, pada terjadinya kerugian keuangan Negara hanya dikenal pembebanan tanggung jawab secara pribadi.

Berdasarkan deskripsi diatas maka pembayaran uang paksa dapat dibebankan kepada diri pribadi pejabat atau badan TUN dan dapat pula dibebankan kepada Negara. Untuk itu pembebanan harus mengacu pada penilaian atas penyebab keterlambatan pelaksanaan putusan pengadilan. Penilaian harus dilakukan dengan cermat karena terkait dengan keuangan pribadi (pejabat atau badan TUN) atau keuangan negara. Apabila keterlambatan tersebut baik langsung atau tidak langsung disebabkan oleh perbuatan atau tindakan yang dilakukan pejabat atau badan TUN diluar penyelenggaraan tugas yang dibebankan kepadanya maka ia berkewajiban untuk menanggung pembayaran uang paksa secara pribadi. Sebaliknya, apabila keterlambatan pelaksanaan putusan pengadilan disebabkan oleh perbuatan atau tindakan yang dilakukan pejabat atau badan TUN sesuai dengan bidang tugas yang dibebankan kepada dan disebabkan olen perbuatan (kebijakan) pemerintah, maka Negara berkewajiban menanggungnya dengan menggunakan uang Negara. Dalam hal ini berlaku prinsip yang diterapkan dalam kerugian keuangan Negara yaitu pembayaran hanya dibebankan kepada pihak yang salah (fairness).

Aspek lain yang harus diperhatikan dalam menerapkan beban pembayaran uang paksa haruslah selalu mengacu pada tujuannya yaitu untuk menimbulkan efek jera yang akan mengubah perilaku pejabat atau badan TUN di masa mendatang. Oleh karena itu besarnya uang yang harus dibayarkan harus diberikan batasan sehingga efektif. Hal ini berlaku baik untuk pembayaran yang dibebankan kepada pribadi maupun kepada Negara. 
Terkait pula dengan pembebanan pembayaran, pengaturan tentang pengumuman pejabat yang tidak melaksanakan putusan pengadilan pada media cetak setempat oleh Panitera (Pasal 116 ayat (5) UU No. 9 Tahun 2004) harus diterapkan dengan cermat pula. Mengacu pada tujuan penetapan uang paksa maka Negara harus menanggung biaya pengumuman sebagai tanggung jawabnya dalam rangka menegakkan hukum.

Ada satu hal yang cukup menggelitik sehubungan dengan pengumuman tersebut perihal nama, apakah yang diumumkan adalah jabatannya atau nama pejabat. Hal ini perlu diatur lebih tegas, karena pencantuman tersebut harus disesuaikan dengan beban pembayaran uang paksa yang ditetapkan. Apabila beban pembayaran ditanggung Negara maka hanya perlu dicantumkan jabatannya. Sedangkan apabila beban pembayaran dilakukan secara pribadi maka yang diumumkan adalah nama pejabat disertai jabatannya. Maka masyarakat akan lebih jeli melihat dan membedakan kesalahan yang terjadi dan lebih selektif dalam memberikan penilaian atas kinerja pejabat. Dengan demikian kontrol sosial dapat dengan tepat dikenakan dan berdampak lebih efektif.

\section{Penutup}

Upaya paksa yang diatur dalam UU No. 9 Tahun 2004 perlu didukung mengingat upaya paksa bertujuan selain untuk memberikan jaminan akan pemenuhan hak tergugat sesuai dengan yang ditetapkan dalam putusan pengadilan TUN yang telah mempunyai kekuatan hukum tetap, juga bertujuan untuk mengubah perilaku pejabat atau badan TUN (selaku tergugat) untuk lebih menghormati dan menjunjung tinggi hukum (putusan pengadilan) baik secar pribadi maupun secara organisasi (pemerintahan). Upaya paksa diberlakukan secara limitatif dan diterapkan secara cermat. Upaya paksa hanya dapat diterapkan bagi putusan yang memuat kewajiban pencabutan keputusan TUN (yang disengketakan) dan menerbitkan keputusan TUN yang baru; dan penerbitan keputusan TUN dalam hal gugatan didasarkan pada Pasal 3.

Uang paksa, merupakan salah satu bentuk upaya paksa, adalah sejumlah uang yang harus dibayarkan oleh tergugat apabila putusan pengadilan belum dilaksanakan melewati waktu yang ditetapkan ( 3 bulan). Pembayaran uang paksa tidak menghapus kewajiban untuk melaksanakan isi putusan tetapi hanya merupakan kompensasi atas keterlambatan dalam melaksanakan putusan tersebut. 
Terkait dengan pembayaran uang paksa perlu dibedakan pembebanannya tergantung pada penyebab terjadinya keterlambatan pelaksanaan putusan. Karena hanya pihak yang melakukan kesalahan yang harus menanggung beban pembayaran. Dengan demikian pembayaran uang paksa dapat dibebankan kepada Negara atau pribadi tergugat tergantung pada letak kesalahannya.

Mengingat pengaturan uang paksa bukanlah merupakan hukuman tetapi hanya sebagai alat untuk mengubah perilaku pejabat atau badan TUN, maka pembebanan pembayaran harus diberikan batasan jumlah. Hal ini dapat diatur lebih lanjut dalam Peraturan Pemerintah atau Peraturan Presiden (sehingga jumlahnya dapat disesuaikan dengan perkembangan ekonomi).

Sesuai dengan tugas dan fungsinya (menengakkan hukum dan keadilan), Negara berkewajiban menanggung biaya yang dikeluarkan untuk mengumumkan pejabat yang tidak melaksanakan putusan pengadilan yang telah mempunyai kekuatan hukum tetap. Pencantuman jabatan dilakukan bagi pembebanan pembayaran uang paksa oleh Negara, sedangkan pencantuman nama pejabat (disertai jabatannya) dilakukan bagi pembebanan pembayaran uang paksa secara pribadi. Hal ini dimaksudkan agar tercapai efektivitas pengawasan sosial dari masyarakat. 


\section{Daftar Pustaka}

Atmosudirdjo, Prajudi. Hukum Administrasi Negara, Jakarta: Ghalia Indonesia, 1988.

Bell, John S and A.W. Bradley. Government Liability: A Comparative Study, London: United Kingdom National Committee of Comparative Law, 1991

Erliyana, Anna. Keputusan Presiden Analisis Keppres R.I. 1987 - 1998, Jakarta: Pasca Sarjana FHUI, 2005.

Errera, R. The Scope and Meaning of No-fault Liability in French Administrative Law, (1986) Current Legal Problems, C. Harlow, Compensation and Government Torts, London, 1982.

Indroharto. Usaha Memahami Undang-Undang Peradilan Tata Usaha Negara, Jakarta: Pustaka Sinar Harapan, 1994.

Kelsen, Hans. General Theory of Law ans State (Terjemahan: Teori Umum Hukum dan Negara), alih bahasa oleh Somardi, Jakarta: Bee Media Indonesia, 2007.

Lotulung, Paulus Effendie. Beberapa Sistem Tentang Kontrol Hukum Terhadap Pemerintah, Jakarta: Bhuana Ilmu Populer, 1986.

Maurer, Hartmut. Allgemeines Verwaltungsrecht, Muenchen: C.H. Beck, 1997.

Mertokusumo, Sudikno. Hukum Acara Perdata Indonesia, Yogyakarta: Liberty, 1988.

Muller, C.F. Staats- und Verwaltungsrecht, Heidelberg, 1997.

RI, Undang-undang No. 5 Tahun 1986 Tentang Peradilan Tata Usaha Negara.

. Undang-undang No. 9 Tahun 2004 Tentang Perubahan atas Undang-Undang No. 5 Tahun 1986 tentang Peradilan Tata Usaha Negara.

Negara.

. Undang-undang No. 17 Tahun 2003 Tentang Keuangan

. Undang-undang No. 1 Tahun 2004 Tentang Perbendaharaan Negara.

Undang-undang No. 15 Tahun 2004 Tentang Pemeriksaan Pengelolaan dan Tanggungjawab Keuangan Negara. 